\title{
Towards Financial Sustainability: Beneficiaries' Perception and Performance of Community Water Supply Services in Ghana
}

\author{
Emmanuel Kwame Nti ${ }^{1,2, \star}$, Camillus Abawiera Wongnaa ${ }^{1}$, Nana Sampson E. Edusah ${ }^{3}$, Dadson Awunyo-Vitor ${ }^{1}$ and \\ Vasco Baffour Kyei ${ }^{1,4}$ \\ ${ }^{1}$ Department of Agricultural Economics, Agribusiness and Extension, Kwame Nkrumah University of Science and \\ Technology, Kumasi, Ghana \\ ${ }^{2}$ Department of Environment and Sustainability Sciences, University for Development Studies, Tamale, Ghana \\ ${ }^{3}$ Bureau of Integrated Rural Development, Kwame Nkrumah University of Science and Technology, Kumasi, Ghana \\ ${ }^{4}$ Akrokerri Small Town Water System, Community Water and Sanitation Agency-Ashanti Region, Kumasi, Ghana
}

*Corresponding author: kwame.nti@yahoo.com; Tel: +23324 0161433

Submitted: 8 August 2020 | In revised form: 21 August 2021 | Accepted: 24 August 2021 |

Published: 29 October 2021

\begin{abstract}
Revenue mobilization is critical for community-managed water systems to overcome financial constraints and to achieve financial sustainability. Using data from beneficiaries of a community managed water supply system in Ghana, we employed descriptive statistics, chi-square, perception index and document review of the system's financial reports to assess beneficiaries' views and perception on revenue mobilization for operations and maintenance, system expansion as well as sustainability of the project. The results showed that revenue mobilization for sustainability of operations and maintenance is significantly influenced by water connection type and religion while marital status, age and income of beneficiaries determine sustainability of the project's expansion. The findings further revealed a significant relationship between sustainability of replacement of the project's accessories and water connection type as well as gender, marital status, age and income of beneficiaries. The average perception index of 3.2 showed that beneficiaries perceived revenue mobilization as very good for replacing the water system's accessories. Revenue mobilization is able to support the water system's expansion to help meet the increasing water demands. In addition, with an average perception index of 3.6, the beneficiaries' perception was that revenue was enough to fund operations and maintenance. Furthermore, the document review of the system's financial reports confirmed beneficiaries' perception of sufficiency of revenue for operations and maintenance. Finally, we found weaknesses in revenue mobilization with over $40 \%$ of bills in arrears, mostly from private users. To build resilience to the financial challenge with enhanced innovations, the study recommends the institution of effective debt recovery strategies such as the provision of pre-paid metering for private users, similar to the public standpipe pay-as-you-fetch system as well as the introduction of smart tap technology for public standpipes in community-managed water supply systems.
\end{abstract}

Keywords: community-managed; financial sustainability; operations and maintenance; revenue; water supply services 


\section{Introduction}

Mobilizing funds from different sources supports longterm financial sustainability [1]. Most evaluation reports revealed that sustainability can greatly be achieved if tariffs generate adequate resources to operate a system, finance the expansion of the service to new customers, and ultimately replace the infrastructure after its useful life [2-4]. This has raised a fundamental question of whether or not any costs should be covered through tariff/billing or external support, be it financially or otherwise. As noted by Nti et al., 2019 [1], most beneficiaries of communitymanaged water systems do not attend community forums organized by management teams aimed at disclosing to beneficiaries the financial position of the system. Thus, most water supply systems, especially those in developing countries, do not get the necessary incentives that allow them to listen to their customers to enable beneficiaries to participate and play a role that could help achieve financial sustainability $[5,6]$. Similarly, what beneficiaries perceive about revenue generation to fund operations, maintenance, expansion and replacement of accessories is critical to ensuring financial sustainability. Gupta and Zeithaml [7] emphasized that beneficiaries are the key ingredients and the lifeblood of any organization and as such their judgments are important. This paper seeks to present the views and perception of beneficiaries on revenue generation in a community-managed water supply system for operations, maintenance, expansion and replacement of accessories needed for meeting financial sustainability standards. Beneficiaries' perception is important in defining financial sustainability because they serve as indicators that help understand and maintain the delivery capacity of water service providers over time while providing new useful clarification to policymakers and others stakeholders [8]. To ensure sustainable and safe water supply, beneficiaries should not just be considered as external users of the water system but a major stakeholder in water point functionality, which is emphasized as part of the water system's performance. In terms of community water supply and environmental sustainability, responsible interaction with beneficiaries helps to ensure sustainable water supply and financial sustainability. These benefits should be provided with the objective of meeting both present and future water needs of beneficiaries without adverse effects on the environment or people or services.

Over the past two decades, development practitioners and scholars have come up with various theoretical models to deepen and widen the understanding of financial sustainability in various sectors and contexts [9]. One such initiative developed in 2001 is the Four Pillars Model of Financial Sustainability by Nature Conservancy in collaboration with the United States Agency for International Development. The model aimed at strengthening capacities to achieve financial sustainability and deliver lasting services without depending on external funding sources [10]. The model posits that organizational financial sustainability comprises four fundamental pillars, viz. strategic and financial planning, income diversification, sound administration and financial management as well as income generation [10]. The income generation pillar is the principal avenue through which organizations can surmount financial constraints and achieve financial sustainability [10].

Small town water systems in Ghana are confronted with inadequate funding and unreliable cash flow for capital maintenance expenditure (CapManEx) from water and sanitation management teams (WSMTs) [11]. When sufficient funds are not set aside by WSMTs, systems have to rely on donors or district assemblies. However, these too are often unreliable and leads to substandard water service delivery $[12,13]$. The current situation with water supply system services in Ghana in terms of inadequate funding and unreliable cash flow for CapManEx from donors and district assemblies calls for improved knowledge to reduce the impact on bills in arrears [11-14]. Looking for an alternative water supply services technology and tariff system could cater for expansion and replacement of accessories devoid of external support. This is crucial because over-reliance on external funding can endanger the sustainability of the entire support system [4].

The challenge with sustainability of water supply systems is that service providers are not normally able to collect full revenues as required [15]. For example, a study by Adank et al. [12] showed that no single service provider sets tariffs to cover capital maintenance costs. For those who set tariffs to cover the aforementioned costs, less than $20 \%$ of them set their tariffs based on projected operational and maintenance costs. The study further reported that between $55 \%$ and $85 \%$ of water committees record annual revenues higher than their actual expenditures. It is, however, not clear as to whether the revenues would be adequate to also cater for the finances of capital maintenance expenditure [12]. In many developing countries, only operations and maintenance costs are eventually charged to customers, while investments are covered by government funding or transfers. This puts water prices at levels acceptable under prevailing social conditions [14]. As emphasized by Barraqué [14], there is a wide array of cost recovery systems using tariffs, taxes and transfers even though it is not obvious that they manage to cover the full costs.

Importantly, few studies cover revenue generation and financial sustainability $[12,14,15]$ even though there are still challenges that affect financial sustainability, including low coverage of rural communities, poor corporate governance practices, diversion of water revenues, among others [16]. The delivery of the small town water system is better organized in terms of sustainability, efficiency, effectiveness and equity when compared to the urban water systems. These are enhanced through gender-balanced WSMTs and a sense of community ownership achieved by community contribution to capital cost [17]. Despite being better organized, financial sustainability remains a problem, particularly for 
the recovery of capital cost, even though most systems are recovering all operational costs [18]. Financial sustainability enables organizations to maintain general operations, ensure continuous delivery of services and invest in infrastructural expansion [9]. The question, however, is whether or not the same can be said of a community-managed water system. Aligning sustainable behavior and education to the needs and knowledge of beneficiaries brings about successful water sustainability $[6,19]$. Unlike cities, small towns often lack the financial and human resources to independently plan, finance, manage and operate their water supply systems [20,21].

Following Al-Shueili [6], the term financial sustainability in the water sector got its first inspiration from one of the principles of the 1992 Dublin conference, which stated that, "water has an economic value and should be considered an economic good and to make it sustainable and affordable, it should be priced appropriately". Financial sustainability in the water sector reflects the financial capability of water users to meet their obligations [6]. The important criteria for achieving sustainability of community water systems are quality drinking water and reliability [1], which cannot materialize without the needed financial sustainability and effective management [22]. Importantly, financial sustainability requires that only revenues collected from the provision of water services delivery should be used to cover all associated costs [23].

The community management model began during the 1990s where project cost sharing became a basis of ensuring financial sustainability [24]. Community management in its actual setup varied in terms of time and setting [25]. The most suitable one is defined basically as the principles where communities have a stake in the development of water supply systems and are generally responsible for the operations and maintenance [26,27]. In Ghana, there are two types of community water systems. The first is the water systems built with support from Community Water and Sanitation Agency (CWSA), Development Partners as well as Metropolitan, Municipal and District Assemblies (MMDAs). Alternatively, the second one is in the form of small towns pipe systems assigned to District Assemblies $[28,29]$. Amerasinghe [30] emphasized that practitioners cite divergent views on the impact of the community management model. For example, research from Rwanda suggests that development practitioners are criticized for the spread of the model because of its limitation regarding lack of professional technical skills, non-payment of user fees and poor financial management [31]. Currently, community management is growing with a clear focus on the importance of professionalism in service delivery [32]. As a result, a phrase termed 'community management plus', with the 'plus' suggesting the continuous support needed to achieve sustainability is proposed by Baumann [33]. This implies clearly defined rules and responsibilities for the community, and local and central government in delivering sustainable services [25].

Operations and maintenance within the community wa- ter supply service are very common terms [34,35]. Operational costs consist of both production and distribution of water, monitoring of water quality through water quality tests, expenses on revenue collection, maintenance and repair works [36]. The term 'operation and maintenance' has three types of activities that are not similar and are qualitatively different from each other. First, operations refer to all the various activities that make the infrastructure work. Second, maintenance includes changing nuts and bolts, greasing pumps, etc. Finally, capital maintenance has to do with renewals and ultimate replacements [37].

The guidelines of CWSA explain that when it comes to the rehabilitation of water systems, it is the responsibility of the WSMTs and, in terms of system expansion, it is the MMDAs that is responsible [38]. Although it is clear that when the expenditure needed to cater for capital maintenance is very high, the MMDAs/central government and/or donors can come in to support and fill the gap: in practice, it is not normally done [15].

From the foregoing, to achieve financial sustainability to help provide more sustainable water supply services, it is important to consider beneficiaries' perception of revenue generation strategies. To do this, the study found answers to the following questions: Q1: What is the extent of beneficiaries' perception on whether revenues are sufficient to pay for operations and maintenance, expansion, as well as replacement of the water system? Q2: Are revenues sufficient to pay for operations and maintenance of the water system? and Q3: Do management financial sustainability pathways depend on external support?

The paper makes the following contributions. First, even though some previous studies have discussed financial sustainability and revenue performance $[12,14,15]$, the present study expands the frontiers of literature on beneficiaries' perception of revenue generation for operations and maintenance, expansion and sustainability of replacement of community water systems. Second, understanding whether revenue is sufficient to pay for operations and maintenance costs of the water system is essential to helping management better appreciate tariffs being collected as well as those in arrears. Through active participation of beneficiaries, this helps build resilience and increases the sustainability of community-managed water systems. Finally, the study contributes to the body of knowledge on whether or not the financial sustainability pathway of a community-managed water system depends on external funding. As a prerequisite, Barraqué [14] noted that improved knowledge leads to better governance of water supply services. This is expected to contribute to policy dialogue and building up improved knowledge as well as stimulate relevant research to aid sector development, not only in water management in Ghana but also in other developing countries. The rest of the paper is organized as follows. The next section presents the methodology. The results are presented and discussed in section three and finally we conclude and make recommendations for policy in section four. 


\section{Materials and Methods}

\subsection{Study Area: The Jacobu Small Town Water Supply System (JSTWSS)}

The Jacobu water supply system serves over 13,000 inhabitants. Jacobu community is the home of the Odotobri constituency and the district capital of Amansie Central District in the Ashanti Region of Ghana. The major sources of drinking water for various households in the Amansie Central District include mechanized bore-hole or tube well, pipe-borne water outside the dwelling, pipe-borne water inside the dwelling as well as public taps or standpipes with shares of $71.1 \%, 6.8 \%, 0.7 \%$ and $12.7 \%$, respectively. The difference between public taps or standpipes and pipeborne water outside the dwelling is that the latter is a pipe water connection to a tap located inside the compound; that is, households that used water from a standpipe located on the compound of the dwelling, while the former is a water point from which the public may collect their water, which is typically located on a street corner or other public space outside a household compound. In the district, rivers or streams also supply $4.4 \%$ of communities' water needs while protected wells supply $3.8 \%$. The use of sachet water is minimal as it constitutes $0.5 \%$ of water needs, which also serves as a source of drinking water for households. Nevertheless, with the majority representing $71.1 \%$ having their drinking water from improved sources, others still depend on unprotected sources of water in the district [39]. With the introduction of the demand-responsive approach, various communities, including Jacobu, obtained access to a water supply with support from the International Development Association (IDA) of the World Bank as a funding agency and the Government of Ghana as a facilitator. The District is among one of the 30 administrative districts in the Ashanti Region of Ghana that was carved out of the Bekwai Municipality in the year 2004. The Jacobu small own water supply project was among the second community water and sanitation project, phase 2, well-known as the small town water supply and sanitation project (STWSSP) in Ghana. The project was completed and partially handed over to the people of Jacobu in 2009. The water system operates three mechanized boreholes as well as two hand pumps and 23 standpipes. The water from the three mechanized boreholes feeds two reinforced concrete elevated tanks of $100 \mathrm{~m}^{3}$ capacity each [40]. Water stored in the two elevated tanks is distributed to 23 public standpipes and 198 private connections as well as other institutions throughout 12 distribution zones in the community. The JSTWSS works under the principle of 'fill and draws', which means that water is pumped into a storage tank before supplying from the tank by gravity to the consumers. Per the operational manual of the Jacobu water system, the average daily water demand is estimated at $657 \mathrm{~m}^{3} /$ day. Out of the $657 \mathrm{~m}^{3} /$ day demand for water in the community, the system was designed to accommodate $30.4 \%$ of the daily water demand, which amounts to the two $100 \mathrm{~m}^{3}\left(200 \mathrm{~m}^{3}\right)$ concrete elevated tanks supplied to the community. However, $40 \%$ of the total average demand of $657 \mathrm{~m}^{3} /$ day can be met over the entire 10 years design life of the project through 12 hour daily pumping and filling of the two $100 \mathrm{~m}^{3}$ concrete elevated tanks [40]. More importantly, it was based on the understanding of the technical expertise of community members trained alongside the project. Several steps were taken to ensure that the project became sustainable and such steps included the training of local community members who worked as laborers alongside the project as technician, pump attendants and manager; training for caretakers on special repairs and maintenance for the system; and an upfront contribution of $10 \%$ of capital costs. The cost of the project was $\mathrm{GH} \$ 772,899.15$, representing $95.7 \%$ of the contract price [40] and its aim was to ensure access to improve water services and improving the living conditions of the people by providing them with clean and safe drinking water for domestic and other purposes.

\subsection{Data Collection}

The sample population for the study consisted of community members/beneficiaries. Using the Yamane (1973) [41] sample size determination formula (Equation 1), a total population $(N)$ of 13,190 and a margin of error $(\alpha)$ of $5 \%$, a sample size of 387 was estimated. Yamane's (1973) [41] sample size determination formula is given as:

$$
n=\frac{N}{1+N(\alpha)^{2}}
$$

The beneficiaries of the system patronized both the private/domestic supply and public standpipes. The framework for revenue collection in both connection types is different. The public standpipe operates on the pay-as-you-fetch principle while the private/domestic connection operates on the monthly billing principle. In sampling respondents for the study, a stratified sampling technique was employed. The sample size for each stratum is given as:

$$
n_{1}=\frac{N_{1} \times S}{N}
$$

Where $n_{1}=$ sample drawn; $N_{1}=$ total number of members of a stratum; $N=$ total population under study; $S=$ sample size for the study. The respondents for the study were categorized into two. These are:

1. Private/Domestic Connection $\left(n_{1}=6\right)$ - beneficiaries who connect the water into their homes and subscribe to the monthly billing principle. With $N_{1}$ of 198 private/domestic metered houses, six were selected in this stratum using Equation 2.

2. Public Standpipe $\left(n_{1}=381\right)$ - beneficiaries who patronize the pay-as-you-fetch public standpipes spread across 23 distribution zones in the community. In this stratum, 381 members were selected using Equation 2.

To maximize the likelihood that all major perspectives were included, qualitative data was also purposively 
collected from a core management team member who is known to be knowledgeable in the subject matter of community managed water supply systems to provide additional data on the external support component of community-managed water supply systems.

3. Core Management $\left(n_{1}=1\right)$ - the WSMT members, operational staff and standpipe vendors.

The study employed a structured survey questionnaire and a key informant interview guide as the primary data collection instruments. The questionnaire was used to collect data from public standpipe users as well as private users. The interview guide was also used to collect data from a core management team member who served as a key informant. To obtain more information on the revenue for operations and maintenance, a document review was conducted focusing on financial records pertaining to the water supply system. The financial record was focused on whether tariffs generate enough revenue for operations and maintenance. The motivation for this was to help in cross-checking the knowledge of beneficiaries when it comes to operations and maintenance of the community-managed water supply system, and to supplement data gained through the interview process from the system's beneficiaries. Document review analysis can be summed up as the process of "evaluating documents in such a way that empirical knowledge is produced and understanding is developed" [42]. Like any other analytical method in qualitative research, document review analysis requires that data be examined and interpreted to elicit meaning, gain understanding, and develop empirical knowledge [42,43]. Employing a document review is important since it occurs without a researcher's intervention and is the only necessary data source for accounting records that need an interpretive paradigm that is appropriate for verifying findings, and provides details that key informants may have forgotten $[42,44]$.

\subsection{Analytical Framework}

Perception index was used to measure the extent of beneficiaries' perception of revenue for operations and maintenance, expansion and/or system replacement. The assumption was that the agreement level must correspond directly to the contributions either positively or negatively. To calculate the perception index, respondents rated each statement using a five-point Likert-scale. The scales were assigned value codes, viz. 1 for Not at all, 2 for Low Extent, 3 for Good Extent, 4 for Very Good Extent and 5 for Great Extent. The mean score for each statement was obtained through a summation of the products of responses for each scale and the respective value codes and dividing by the overall responses (samples size). Mathematically, this is expressed as follows:

$$
\text { Average Perception Score }=\frac{\sum P S S_{i} V_{i}}{\sum P_{i}}
$$

Where;

$P S S_{i}$ is the summation of the frequency of a Particular Statement Scale (PSS);

$V_{i}$ is the value assigned to each scale; and

$P_{i}$ is the total number of respondents/persons $(\mathrm{P})$ who answered the questions.

The perception statements for this study consisted of statements extracted from evaluation reports on project completion, which stated that "sustainability can highly be achieved if tariffs generate adequate resources to operate the system, finance the expansion of the service to new customers, and ultimately replace the infrastructure after its useful life" [2-4]. The beneficiaries' background attributes were cross-tabulated against financial sustainability measured in terms of the views of the beneficiaries on revenue sufficiency on operations and maintenance, expansion and replacement. The beneficiaries responded to the perception statements based on their level of agreement. No answer was rejected, hence 368, 327 and 236 responses were analyzed at a response rate of $95.09 \%, 84.50 \%$ and $60.98 \%$, respectively, using Equation 4 . The average response rate was calculated to be $80.19 \%$ and, according to Baruch [45], there is no norm as to what an acceptable response rate in academia is, even though a response rate of $80 \%$ and above is preferred. However, a clear description of the viewpoints of respondents shown in Table 1 and an average response rate of $80.19 \%$ is appropriate to confirm the absence of response bias in this study. The response rate is given as:

$$
\text { Response Rate }(\mathrm{RR})=\frac{\text { Valid Responses }}{\text { Estimated Sample Size }} \times 100
$$


Table 1. Description of the viewpoints.

\begin{tabular}{llll}
\hline $\begin{array}{l}\text { Perception } \\
\text { Responses }\end{array}$ & Descriptor & Description of viewpoint \\
\hline 1 & 368 & $\begin{array}{l}\text { Operations and maintenance } \\
\text { sustainability }\end{array}$ & $\begin{array}{l}\text { The viewpoint of operations and maintenance sustainability } \\
\text { emphasizes the capacity for financial commitment that makes a water } \\
\text { supply infrastructure work to provide adequate water for all purposes. } \\
\text { The viewpoint of expansion sustainability supports the means of } \\
\text { augmentation of water infrastructure to accommodate new } \\
\text { users/settlements as the population of the community grows that } \\
\text { cannot be catered for by the current system's capacity. It is different } \\
\text { from the extension that is to enable connection to be catered for by } \\
\text { the current system capacity. }\end{array}$ \\
& Expansion sustainability & $\begin{array}{l}\text { Emphasizes the provision of water equivalent to the pre-system } \\
\text { quality and quantity, provision of an equivalent water delivery system } \\
\text { and payment of operation and maintenance costs over costs that } \\
\text { would be customary and reasonable for the delivery of such supplies. } \\
\text { Yet, does the tariff allow for the upkeep of the infrastructure and } \\
\text { replacing the ageing parts? }\end{array}$ \\
\hline
\end{tabular}

In employing document review analysis to reveal whether revenue is sufficient to pay for operations and maintenance costs of the water system, O'Leary [46] provided two major techniques in exploring the actual content of the documents. The first technique employed in this study is where the audited financial report was treated as the respondent or key informant that provides the researcher with relevant information. The second technique is a content analysis and in this technique, the researcher quantifies the use of particular words, phrases and concepts [46].

\section{Results and Discussions}

\subsection{Beneficiaries' Attributes and Perception of Operations and Maintenance, Expansion and/or Replacement}

The study captured information on beneficiaries' background attributes, including connection type, gender, marital status, educational level, age, religion and income. With regards to connection type, the perception of beneficiaries on sustainability of operations and maintenance (O\&M) as indicated in Table 2 shows that of the 368 beneficiaries who perceived YES, 98.91\% were public standpipe users while $1.09 \%$ were domestic/private users. The result suggests up to a $99 \%$ probability of financial sustainability of O\&M having a significant relationship with beneficiaries' connection type. The implication is that views on financial sustainability of O\&M varied significantly among beneficiaries in the two connection type categories.

In terms of religion, $86.82 \%$ of the beneficiaries were Christians, $11.37 \%$ were Muslims and $1.81 \%$ were traditionalists. Among the beneficiaries who perceived YES for revenue sufficiency for O\&M, up to $87.23 \%$ were Christians. Similarly, for those who perceived NO for revenue sufficiency for O\&M, Christians (78.95\%) formed the majority. This was followed by $15.79 \%$ who were Traditionalists and $5.26 \%$ representing Muslims. The result suggests up to a $99 \%$ chance of financial sustainability of O\&M having a significant association with beneficiaries' religion. This study has therefore revealed a significant relationship between religion and sustainability of operations and maintenance. This is so because religion is known to be associated with moral principles that allow people to be more faithful and responsible [47]. Conversely, previous studies have reported that high rates of participation in religious activities does not necessarily result in higher income [47]. The findings are novel since very little was known about the significant relationship between religion and financial sustainability, especially in operations and maintenance of community water management.

The perception of beneficiaries on sustainability of expansion is significantly related to marital status, age and income (Table 3). The study revealed that for married couples, $43.43 \%$ of beneficiaries perceived YES even though beneficiaries who are single formed the majority of those who perceived NO. The result suggests up to a $99 \%$ likelihood of financial sustainability on system expansion being significantly related to beneficiaries' marital status. This finding corroborates those of previous studies that showed that marital stability is positively associated with financial resources $[48,49]$. With regards to the age of beneficiaries, Table 3 shows that of the 387 respondents, $36.69 \%$ were between the age brackets of $18-30$ years, $57.62 \%$ were between the age brackets of $31-59$ years and $5.69 \%$ were over 60 years. The result suggests up to $95 \%$ probability of financial sustainability of system expansion having a significant relationship with beneficiaries' age. This finding is consistent with similar ones reported by Bolivar et al. [8] that reported that the existence of an ageing population influences financial sustainability of community managed water supply projects.

On income, $47.60 \%$ of beneficiaries within the $\mathrm{GH} \$ 501$ 1000 income bracket perceived YES for revenue sufficiency for expansion while beneficiaries within the same income bracket representing $49.15 \%$ perceived NO. This result reveals a $95 \%$ statistically significant association between financial sustainability of system expansion and beneficiaries' income, which suggests that views regarding financial 
sustainability of system expansion varied significantly depending on the income of beneficiaries. The perception of beneficiaries on sustainability of expansion to new users or customers is significantly related to income. This is in line with a study in Malaysia that found income to be a significant variable, which pushed aid policymakers to review existing social security frameworks towards financial sustainability [50]. Table 3 presents the beneficiaries' attributes and perception of system expansion.

To also illustrate the perception of beneficiaries on sustainability of replacement of the system, the results in Table 4 show that it was significantly related to connection type, gender, marital status, age and income. Of the 236 beneficiaries who perceived YES for connection type, 97.46\% were public standpipe users while $2.54 \%$ were domestic/private users. With regards to the age of beneficiaries, the result suggests up to a $90 \%$ chance of financial sustainability of replacement of the system having a significant association with beneficiaries' age. This could be attributed to the fact that the age of beneficiaries who are working and are generating revenues could contribute to achieving the financial sustainability of their community-managed water system, which serves them as they work in their locality [8].

Table 2. Cross-tabulation of beneficiaries' attributes and perception of O\&M.

\begin{tabular}{|c|c|c|c|c|c|c|c|c|c|}
\hline \multirow{3}{*}{ Beneficiaries' attributes } & \multicolumn{6}{|c|}{ Operations and Maintenance } & \multicolumn{3}{|c|}{ Summary of chi-square results } \\
\hline & \multicolumn{2}{|l|}{ Yes } & \multicolumn{2}{|l|}{ No } & \multicolumn{2}{|l|}{ Total } & \multirow[b]{2}{*}{$\mathrm{x}^{2}$} & \multirow[b]{2}{*}{$\mathrm{df}$} & \multirow[b]{2}{*}{$\mathrm{p}$-value } \\
\hline & Freq. & $\%$ & Freq. & $\%$ & Freq. & $\%$ & & & \\
\hline \multicolumn{10}{|l|}{ Connection type } \\
\hline Domestic type & 4 & 1.09 & 2 & 10.53 & 6 & 1.55 & \multirow{3}{*}{10.5468} & \multirow{3}{*}{1} & \multirow{3}{*}{$0.001^{* *}$} \\
\hline Public standpipe & 364 & 98.91 & 17 & 89.47 & 381 & 98.45 & & & \\
\hline Total & 368 & 100 & 19 & 100 & 387 & 100 & & & \\
\hline \multicolumn{10}{|l|}{ Gender of beneficiaries } \\
\hline Male & 159 & 43.21 & 11 & 57.89 & 170 & 43.93 & \multirow{3}{*}{1.5825} & \multirow{3}{*}{1} & \multirow{3}{*}{0.208} \\
\hline Female & 209 & 56.79 & 8 & 42.11 & 217 & 56.07 & & & \\
\hline Total & 368 & 100 & 19 & 100 & 387 & 100 & & & \\
\hline \multicolumn{10}{|l|}{ Marital status } \\
\hline Single & 221 & 60.05 & 12 & 63.16 & 233 & 60.21 & \multirow{3}{*}{0.0726} & \multirow{3}{*}{1} & \multirow{3}{*}{0.788} \\
\hline Married & 147 & 39.95 & 7 & 36.84 & 154 & 39.79 & & & \\
\hline Total & 368 & 100 & 19 & 100 & 387 & 100 & & & \\
\hline \multicolumn{10}{|l|}{ Educational level } \\
\hline No Formal Edu. & 14 & 3.80 & 0 & 0 & 14 & 3.63 & \multirow{6}{*}{3.8526} & \multirow{6}{*}{4} & \multirow{6}{*}{0.426} \\
\hline Primary school & 14 & 3.80 & 0 & 0 & 14 & 3.63 & & & \\
\hline Middle/JHS/JSS & 130 & 35.33 & 5 & 27.78 & 135 & 34.97 & & & \\
\hline SSS/SHS & 114 & 30.98 & 5 & 27.78 & 119 & 30.83 & & & \\
\hline College/Terciary & 96 & 26.09 & 8 & 44.44 & 104 & 26.94 & & & \\
\hline Total & 368 & 100 & 18 & 100 & 386 & 100 & & & \\
\hline Age & & & & & & & & & \\
\hline $18-30$ years & 134 & 36.41 & 8 & 42.11 & 142 & 36.69 & & & \\
\hline $31-59$ years & 213 & 57.88 & 10 & 52.63 & 223 & 57.62 & 0.2522 & 2 & 0.882 \\
\hline $60+$ years & 21 & 5.71 & 1 & 5.26 & 22 & 5.69 & & & \\
\hline Total & 368 & 100 & 19 & 100 & 387 & 100 & & & \\
\hline Religion & & & & & & & & & \\
\hline Christian & 321 & 87.23 & 15 & 78.95 & 336 & 86.82 & & & \\
\hline Islam & 43 & 11.68 & 1 & 5.26 & 44 & 11.37 & 223897 & 2 & $0.000^{* * *}$ \\
\hline Traditional & 4 & 1.09 & 3 & 15.79 & 7 & 1.81 & 22.0091 & 2 & \\
\hline Total & 368 & 100 & 19 & 100 & 387 & 100 & & & \\
\hline Income & & & & & & & & & \\
\hline $\mathrm{GH} \pitchfork 0-500$ & 79 & 22.25 & 4 & 23.53 & 83 & 22.31 & & & \\
\hline $\mathrm{GH} \$ 501-1000$ & 169 & 47.61 & 9 & 52.94 & 178 & 47.85 & & & \\
\hline $\mathrm{GH} \$ 1001-2000$ & 86 & 24.23 & 4 & 23.53 & 90 & 24.19 & 1.1172 & 3 & 0.773 \\
\hline $\mathrm{GH} \$ 2001+$ & 21 & 5.92 & 0 & 0 & 21 & 5.65 & & & \\
\hline Total & 355 & 100 & 17 & 100 & 372 & 100 & & & \\
\hline
\end{tabular}

Note: the asterisks, ${ }^{*},{ }^{* *}$, and ${ }^{* * *}$ indicate significance levels of $10 \%, 5 \%$, and $1 \%$, respectively. 
For income, as explained by Bolívar et al. [8], an adjusted income statement that does not include revenues and expenditures is sufficient to assess financial sustainability. In that way, beneficiaries' incomes also become a useful measure to sustain public services, especially water services over time towards financial sustainability. From Table 4 , the majority of beneficiaries who perceived YES for revenue sufficiency for sustainability of expansion to new users (42.60\%) were within an income bracket of GH\$507-1000. The analysis revealed up to a $99 \%$ statistically significant relationship between financial sustainability of system replacement and beneficiaries' income. The implication is that views regarding financial sustainability of system replacement vary significantly among beneficiaries in the income categories. Our findings are in consonance with those of Bolivar et al. [51] and Subires et al. [52] who reported that the demand for financial information, as evident in the stakeholder's theory, has also increased the pressure of many of the institutions, be it government and/or non-governmental institutions, and in our case water supply systems to monitor public opinions on finances. This is in line with the findings of previous studies that identified income as a comprehensive factor that influences financial sustainability of public services [50].

Table 3. Cross-tabulation of beneficiaries' attributes and perception on system expansion.

\begin{tabular}{|c|c|c|c|c|c|c|c|c|c|}
\hline \multirow{3}{*}{ Beneficiaries' attributes } & \multicolumn{6}{|c|}{ Operations and Maintenance } & \multicolumn{3}{|c|}{ Summary of chi-square results } \\
\hline & \multicolumn{2}{|l|}{ Yes } & \multicolumn{2}{|l|}{ No } & \multicolumn{2}{|l|}{ Total } & \multirow[b]{2}{*}{$\mathrm{x}^{2}$} & \multirow[b]{2}{*}{$\mathrm{df}$} & \multirow[b]{2}{*}{$p$-value } \\
\hline & Freq. & $\%$ & Freq. & $\%$ & Freq. & $\%$ & & & \\
\hline \multicolumn{10}{|l|}{ Connection type } \\
\hline Domestic type & 6 & 1.83 & 0 & 0 & 6 & 1.55 & \multirow{3}{*}{1.1183} & \multirow{3}{*}{1} & \multirow{3}{*}{0.290} \\
\hline Public standpipe & 321 & 98.17 & 60 & 100 & 381 & 98.45 & & & \\
\hline Total & 327 & 100 & 60 & 100 & 387 & 100 & & & \\
\hline \multicolumn{10}{|l|}{ Gender of beneficiaries } \\
\hline Male & 146 & 44.65 & 24 & 40 & 170 & 43.93 & \multirow{3}{*}{0.4447} & \multirow{3}{*}{1} & \multirow{3}{*}{0.505} \\
\hline Female & 181 & 55.35 & 36 & 60 & 217 & 56.07 & & & \\
\hline Total & 327 & 100 & 60 & 100 & 387 & 100 & & & \\
\hline \multicolumn{10}{|l|}{ Marital status } \\
\hline Single & 185 & 56.57 & 48 & 80 & 233 & 60.20 & \multirow{3}{*}{11.6117} & \multirow{3}{*}{1} & \multirow{3}{*}{$0.001^{* *}$} \\
\hline Married & 142 & 43.43 & 12 & 20 & 154 & 39.80 & & & \\
\hline Total & 327 & 100 & 60 & 100 & 387 & 100 & & & \\
\hline \multicolumn{10}{|l|}{ Educational level } \\
\hline No Formal Edu. & 13 & 3.98 & 1 & 1.69 & 14 & 3.63 & \multirow{6}{*}{2.9040} & \multirow{6}{*}{4} & \multirow{6}{*}{0.574} \\
\hline Primary school & 12 & 3.67 & 2 & 3.39 & 14 & 3.63 & & & \\
\hline Middle/JHS/JSS & 113 & 34.56 & 22 & 37.29 & 135 & 34.97 & & & \\
\hline SSS/SHS & 97 & 29.66 & 22 & 37.29 & 119 & 30.83 & & & \\
\hline College/Terciary & 92 & 28.13 & 12 & 20.34 & 104 & 26.94 & & & \\
\hline Total & 327 & 100 & 59 & 100 & 386 & 100 & & & \\
\hline Age & & & & & & & & & \\
\hline $18-30$ years & 128 & 39.14 & 14 & 23.33 & 142 & 36.70 & & & \\
\hline $31-59$ years & 179 & 54.74 & 44 & 73.33 & 223 & 57.62 & 7.1861 & 2 & $0.028^{*}$ \\
\hline $60+$ years & 20 & 6.12 & 2 & 3.33 & 22 & 5.68 & 1.1861 & 2 & \\
\hline Total & 327 & 100 & 60 & 100 & 387 & 100 & & & \\
\hline Religion & & & & & & & & & \\
\hline Christian & 288 & 88.07 & 48 & 80 & 336 & 86.82 & & & \\
\hline Islam & 34 & 10.40 & 10 & 16.67 & 44 & 11.37 & 3.0456 & 2 & 0.218 \\
\hline Traditional & 5 & 1.53 & 2 & 3.33 & 7 & 1.81 & 3.0456 & 2 & 0.210 \\
\hline Total & 327 & 100 & 60 & 100 & 387 & 100 & & & \\
\hline Income & & & & & & & & & \\
\hline $\mathrm{GH} \pitchfork 0-500$ & 64 & 20.45 & 19 & 32.20 & 83 & 22.31 & & & \\
\hline $\mathrm{GH} \$ 501-1000$ & 149 & 47.60 & 29 & 49.15 & 178 & 47.85 & & & \\
\hline $\mathrm{GH} \$ 1001-2000$ & 79 & 25.24 & 11 & 18.64 & 90 & 24.20 & 7.9509 & 3 & $0.047^{*}$ \\
\hline $\mathrm{GH} \$ 2001+$ & 21 & 6.71 & 0 & 0 & 21 & 5.65 & & & \\
\hline Total & 313 & 100 & 59 & 100 & 372 & 100 & & & \\
\hline
\end{tabular}

Note: the asterisks, ${ }^{*},{ }^{* *}$, and ${ }^{* \star *}$ indicate significance levels of $10 \%, 5 \%$, and $1 \%$, respectively. 
Table 4. Cross-tabulation of beneficiaries' attributes and perception of replacement.

\begin{tabular}{|c|c|c|c|c|c|c|c|c|c|}
\hline \multirow{3}{*}{ Beneficiaries' attributes } & \multicolumn{6}{|c|}{ System Replacement/Recovery } & \multicolumn{3}{|c|}{ Summary of chi-square results } \\
\hline & \multicolumn{2}{|l|}{ Yes } & \multicolumn{2}{|l|}{ No } & \multicolumn{2}{|l|}{ Total } & \multirow[b]{2}{*}{$x^{2}$} & \multirow[b]{2}{*}{ df } & \multirow[b]{2}{*}{$\mathrm{p}$-value } \\
\hline & Freq. & $\%$ & Freq. & $\%$ & Freq. & $\%$ & & & \\
\hline \multicolumn{10}{|l|}{ Connection type } \\
\hline Domestic type & 6 & 2.54 & 0 & 0 & 6 & 1.55 & \multirow{3}{*}{3.8994} & \multirow{3}{*}{1} & \multirow{3}{*}{$0.048^{*}$} \\
\hline Public standpipe & 230 & 97.46 & 151 & 100 & 381 & 98.45 & & & \\
\hline Total & 236 & 100 & 151 & 100 & 387 & 100 & & & \\
\hline \multicolumn{10}{|l|}{ Gender of beneficiaries } \\
\hline Male & 114 & 48.31 & 56 & 37.09 & 170 & 43.93 & \multirow{3}{*}{4.7054} & \multirow{3}{*}{1} & \multirow{3}{*}{$0.030^{*}$} \\
\hline Female & 122 & 51.69 & 95 & 62.91 & 217 & 56.07 & & & \\
\hline Total & 236 & 100 & 151 & 100 & 387 & 100 & & & \\
\hline \multicolumn{10}{|l|}{ Marital status } \\
\hline Single & 134 & 56.78 & 99 & 65.56 & 233 & 60.21 & \multirow{3}{*}{2.9651} & \multirow{3}{*}{1} & \multirow{3}{*}{$0.085^{*}$} \\
\hline Married & 102 & 43.22 & 52 & 34.44 & 154 & 39.79 & & & \\
\hline Total & 236 & 100 & 151 & 100 & 387 & 100 & & & \\
\hline \multicolumn{10}{|l|}{ Educational level } \\
\hline No Formal Edu. & 12 & 5.08 & 2 & 1.33 & 14 & 3.63 & \multirow{6}{*}{5.4272} & \multirow{6}{*}{4} & \multirow{6}{*}{0.246} \\
\hline Primary school & 9 & 3.81 & 5 & 3.33 & 14 & 3.63 & & & \\
\hline Middle/JHS/JSS & 85 & 36.02 & 50 & 33.3 & 135 & 34.97 & & & \\
\hline SSS/SHS & 66 & 27.97 & 53 & 35.33 & 119 & 30.83 & & & \\
\hline College/Terciary & 64 & 27.12 & 40 & 26.67 & 104 & 26.94 & & & \\
\hline Total & 236 & 100 & 150 & 100 & 386 & 100 & & & \\
\hline Age & & & & & & & & & \\
\hline $18-30$ years & 89 & 37.71 & 53 & 35.10 & 142 & 36.69 & & & \\
\hline $31-59$ years & 129 & 54.66 & 94 & 62.25 & 223 & 57.62 & 5.1062 & 2 & $0.078^{*}$ \\
\hline $60+$ years & 18 & 7.63 & 4 & 2.65 & 22 & 5.69 & 5.1062 & 2 & $0.0 / 8$ \\
\hline Total & 236 & 100 & 151 & 100 & 387 & 100 & & & \\
\hline Religion & & & & & & & & & \\
\hline Christian & 210 & 88.98 & 126 & 83.45 & 336 & 86.82 & & & \\
\hline Islam & 21 & 8.90 & 23 & 15.23 & 44 & 11.37 & 38953 & 2 & 0.143 \\
\hline Traditional & 5 & 2.12 & 2 & 1.32 & 7 & 1.81 & 3.8953 & 2 & \\
\hline Total & 236 & 100 & 151 & 100 & 387 & 100 & & & \\
\hline Income & & & & & & & & & \\
\hline $\mathrm{GH} \pitchfork 0-500$ & 44 & 19.73 & 39 & 26.17 & 83 & 22.31 & & & \\
\hline $\mathrm{GH} \$ 501-1000$ & 95 & 42.60 & 83 & 55.71 & 178 & 47.85 & & & \\
\hline $\mathrm{GH} \$ 1001-2000$ & 64 & 28.70 & 26 & 17.45 & 90 & 24.19 & 20.4332 & 3 & $0.000^{\star \star *}$ \\
\hline $\mathrm{GH} \$ 2001+$ & 20 & 8.97 & 1 & 0.67 & 21 & 5.65 & & & \\
\hline Total & 223 & 100 & 149 & 100 & 372 & 100 & & & \\
\hline
\end{tabular}

Note: the asterisks, ${ }^{*},{ }^{* *}$, and ${ }^{* * *}$ indicate significance levels of $10 \%, 5 \%$, and $1 \%$, respectively.

\subsection{Extent of Beneficiaries' Perception}

With regards to the first research question, the study sought to address the extent of beneficiaries' perception on whether revenue is sufficient to pay for operations and maintenance, expansion and/or replacement of the water system. Figure 1 showed that $95.09 \%$ of the beneficiaries were of the view that the amount they pay for using the system's water is sufficient to pay for the operations and maintenance, while only $4.91 \%$ were of the opposing view. On whether the revenue generated is sufficient to expand the system, $84.46 \%$ were of the view that the money they pay would be able to expand the system, whereas $15.54 \%$ responded otherwise (Figure 1 ). The implication is that the majority of the beneficiaries were in line with the firm's perception that the revenue generated could help expand the water system to new customers/settlements. About the perception of replacement of the system, $60.98 \%$ of the beneficiaries perceived that the revenue collected by management of the system should be able to replace the infrastructure, while $39.02 \%$ perceived otherwise. This implies that the majority of the beneficiaries perceived that the money that they pay can fund the replacement of the water infrastructure. 


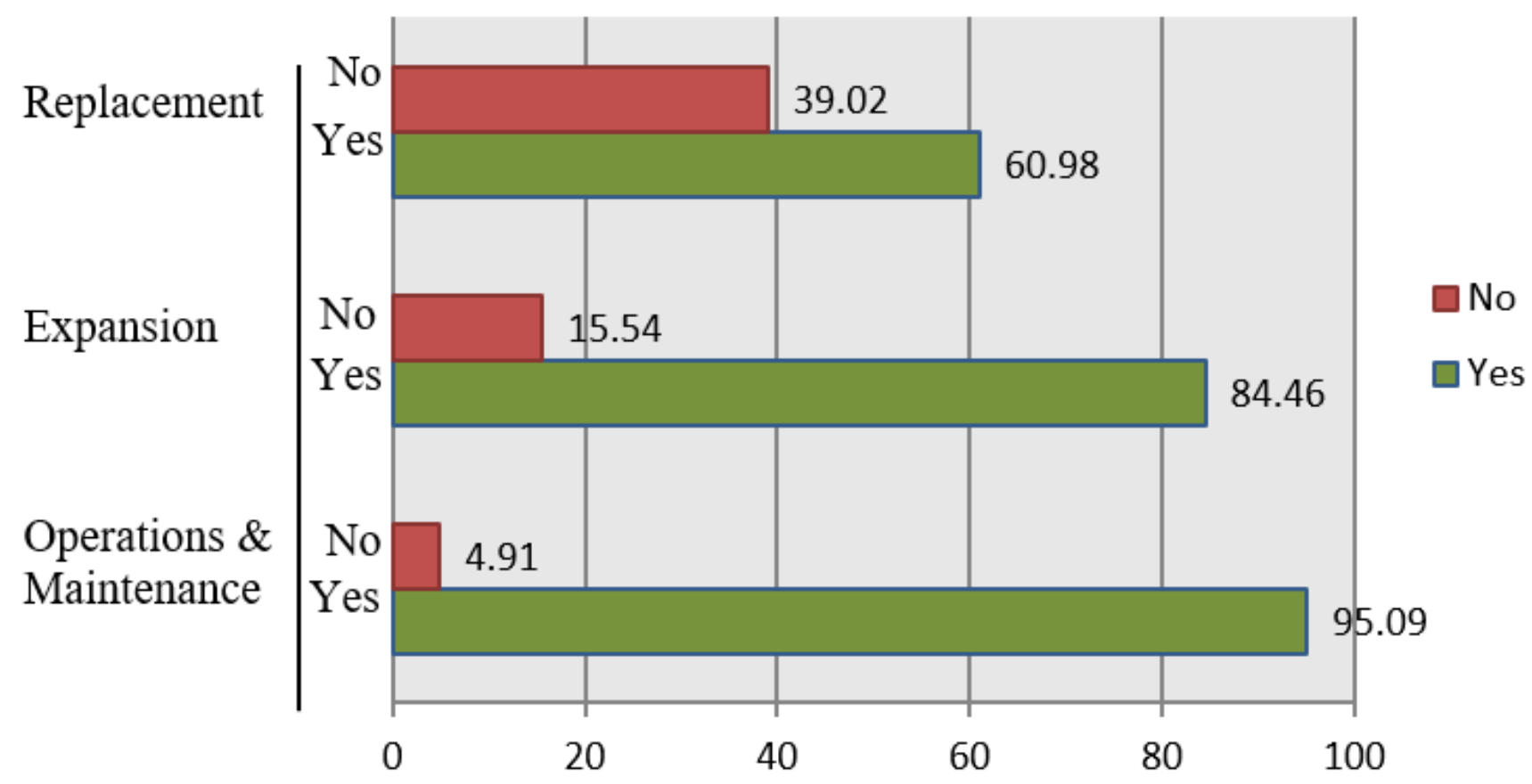

Figure 1. Perception of revenue for operations, expansion and system replacement.

The respondents were asked to determine the extent to which the money that they pay would be sufficient to pay for operations and maintenance costs. The majority of the respondents (32\%) were of the view that the money they pay was sufficient to cover the operations and maintenance costs. Moreover, the estimated perception index of 3.6 implies that, to a very good extent, monies paid by beneficiaries would be enough to meet the operations and maintenance costs of running the community managed water project. The views of the remaining $68 \%$ of the beneficiaries on whether revenue to the firm is sufficient to pay operations and maintenance are such that $1 \%$ indicated not at all, $21 \%$ indicated to a low extent, $25 \%$ indicated to a good extent and another $21 \%$ indicated to a very good extent.

In terms of system expansion, only $1 \%$ of the beneficiaries indicated not at all while $19 \%$ indicated to a great extent. With an average perception index of 3.1, which lies between good and very good extent, we conclude that, to a very good extent, beneficiaries have a positive perception of revenues collected being able to cater for the system's expansion. However, the majority of the respondents representing $45 \%$ indicated that revenue, to a very low extent, was sufficient to expand the system. Meanwhile, to a very great extent, close to a fifth (19\%) of the respondents expressed their perception of revenue mobilization being able to enhance the system's expansion.

On the perception of the beneficiaries as to whether the money they pay is sufficient to replace the infrastructure, only $3 \%$ indicated not at all while $26 \%$ indicated to a great extent. Thus, to a very low extent, the majority of the ben- eficiaries (37\%) were of the view that the monies paid to the firm were sufficient to pay for the replacement of the system after its useful life. Generally, perception on revenue mobilization capacity to replace the infrastructure revealed a perception index of 3.2, which lies between to a good and to a very good extent. Table 5 presents the perception index on the extent of revenue sufficiency for operations and maintenance, expansion and/or system replacement.

Averagely, beneficiaries' perception on revenue being able to cover operations and maintenance, expansion and replacement of the infrastructure after its useful life is positive. To a very good extent, the computed perception index of 3.3 confirms this. The implication is that most beneficiaries think that revenue generated should help in achieving financial sustainability of the system just as most evaluation reports revealed adequately operating the system, financing expansion and replacing the infrastructure [2-4].

In this study, the operations and maintenance viewpoint was made the dominant factor in the opinion of the beneficiaries with the firm belief that the revenues they generate can sufficiently fund the operations and maintenance of the system. None of the three distinct perspectives in the opinion of the beneficiaries of the water system believed that revenue generated could not fund the system expansion and/or replacement. This viewpoint was in line with the need for better management that would lead to financial sustainability of most community-managed water supply systems. Generally, opportunities exist for improving the understanding of beneficiaries about revenue generation and financial sustainability of community managed water supply systems. 
Table 5. Perception Index on the extent of revenue sufficiency for operations and maintenance, expansion and/or replacement.

\begin{tabular}{|c|c|c|c|c|c|c|c|c|c|c|c|}
\hline \multirow{2}{*}{$\begin{array}{l}\text { Perceptions/ } \\
\text { viewpoint }\end{array}$} & \multicolumn{2}{|c|}{ (1) Not at all } & \multicolumn{2}{|c|}{ (2) Low Extent } & \multicolumn{2}{|c|}{ (3) Good Extent } & \multicolumn{2}{|c|}{ (4) Very Good Extent } & \multicolumn{2}{|c|}{ (5) Great Extent } & \multirow{2}{*}{$\begin{array}{l}\text { Average } \\
\text { Index }\end{array}$} \\
\hline & Freq. & $\%$ & Freq. & $\%$ & Freq. & $\%$ & Freq. & $\%$ & Freq. & $\%$ & \\
\hline $\begin{array}{l}\text { To what extent is revenue paid } \\
\text { sufficient to pay for operations and } \\
\text { maintenance }\end{array}$ & 2 & 1 & 78 & 21 & 92 & 25 & 78 & 21 & 120 & 32 & 3.6 \\
\hline $\begin{array}{l}\text { To what extent is revenue paid } \\
\text { sufficient to expand the water supply } \\
\text { system }\end{array}$ & 2 & 1 & 147 & 45 & 65 & 20 & 50 & 15 & 63 & 19 & 3.1 \\
\hline $\begin{array}{l}\text { To what extent is revenue paid } \\
\text { sufficient for the systems replacement } \\
\text { after its useful use }\end{array}$ & 8 & 3 & 89 & 37 & 46 & 19 & 35 & 15 & 61 & 26 & 3.2 \\
\hline Perception Index Score & & & & & & & & & & & 3.3 \\
\hline
\end{tabular}

Source: Field Survey, 2018.

\subsection{Revenue to Cover Operations and Maintenance Costs}

Sources of revenue of water systems mostly stem from revenue from standpipes, private connections, registration fees, external support, treasury bills, fines and other forms of income. The results revealed that revenue from standpipes constitutes the highest source of revenue for a community-managed water system. Standpipes generated about $62 \%$ of total revenue. This was followed by private connections, which generated about $36 \%$ with the remaining sources of income constituting only $2 \%$ (Figure 2 and Figure 3). The implication is that the major sources of revenue to community managed water systems are standpipes and private connections. The document review revealed that although private connections generated $36 \%$ of total firm revenues, the management of the system could not recover all monies from its customers during the years under review.

It was revealed that there are many arrears in the payment of the post-paid monthly bills for private/domestic connection beneficiaries. Defaulters/debtors constitute about $17.1 \%$ of the actual revenue accrued by the system and almost $60.24 \%$ of total revenue billed to private connections alone. This suggests that the majority of the beneficiaries were not able to pay their bills after using water from the system. This was common among patrons of a post-paid system for private connections in community-managed systems. This could be attributed to the fact that although individual metering at the household level could face disconnection for non-payment of bills, the bills remain unpaid even after disconnecting the customer. This finding agrees with those of Fonseca et al. [15] that service providers are not normally able to collect or generate full revenues as required and this affects the sustainability of water supply systems. The analysis showed that private (household) connections had significantly more debtors than any other revenue source and, therefore, management should take a critical look at private connections since more defaults will affect the system's future revenue mobilization.

We could indeed argue that those who patronize the public standpipe pay-as-you-fetch indirectly fund the water system through the daily revenue mobilization that the private/domestic consumers enjoy even though they are the customers with more arrears in the payment of monthly bills. There is the need to implement measures to ensure that the water bills of private/domestic consumers are paid on time to eliminate any need for public standpipe pay-as-you-fetch users to subsidize non-paying private/domestic users. Such funds are collected on an ad-hoc basis only when it is needed. However, taking more than a year to collect the monies that are needed to manage the system will have a negative implication on financial sustainability, unlike the public standpipe pay-as-you-fetch. This implies that it will be difficult to improve on specific service delivery standards over time. What seems to be more worrying is that increasing private/domestic water supply to households with the same post-paid system will mean that public standpipe users would drop together with the revenue received from the pay-as-you-fetch that supports the system, which would result in financial challenges affecting the sustainability of the system.

About $79 \%$ of the total income accrued by the system goes into expenditures. From the study, operations and maintenance expenditures represent about $16.2 \%$ of the projected expenditure and $15.8 \%$ of the actual revenue accrued for the system. This implies that between $15.8 \%$ and $16.2 \%$ of the system's revenue is spent on operations and maintenance, indicating that the system's revenue is somewhat sufficient to pay for operations and maintenance as far as the management of the community water system is concerned. This aligns with the statement that between $55 \%$ and $85 \%$ of the water committee or management team record annual revenue that is higher than their actual expenditure. This depicts that funds needed for operational expenditure are below the accumulated accrued revenue [12]. The result reflects similar findings reported by Fonseca et al. [15] that in exceptional and incomparable cases, service providers mobilize revenue that is sufficient to pay for operations and capital maintenance costs. 


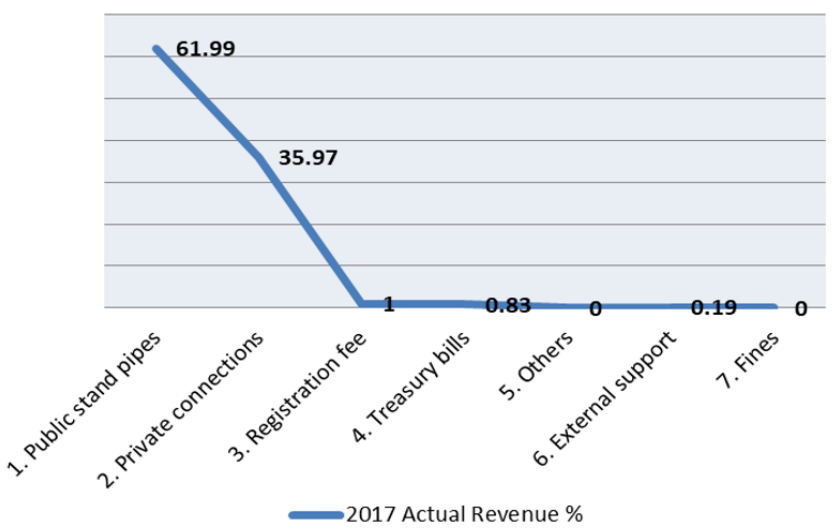

Figure 2. Revenue head for 2017.

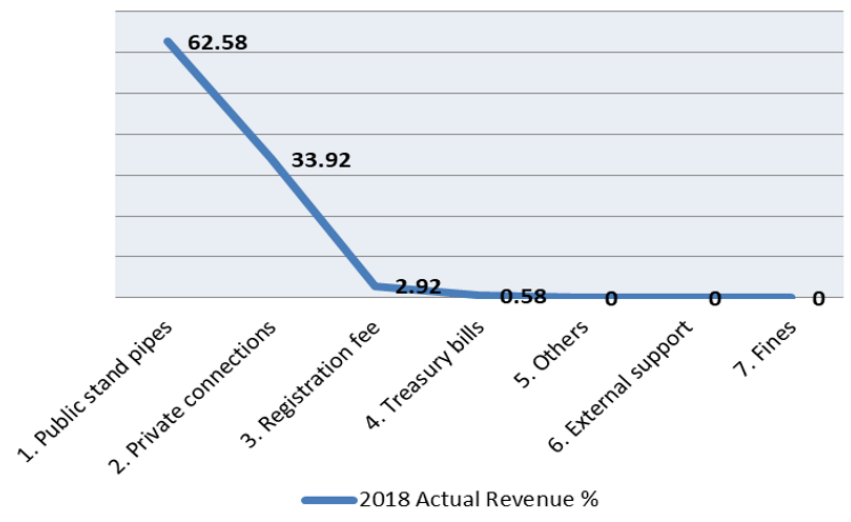

Figure 3. Revenue head for 2018.

\subsection{External Support for Community-Managed Water Systems and Accounts Operation}

The by-law of the MLGRD states that the assemblies, be it metropolitan, municipal or district, may apportion funds every year from their regular budgetary allocations to the capital account for water development [53]. It has been revealed in this study that such compliance has not been followed by the District Assembly since the handing over of the project to the community in 2009. This is evident in the saying: "The system has not received any funds from the assembly as support since 2009 when it was handed over to the community. I have always been asking for it since the bye-law has stated that during any opportunity I get in a meeting concerning the water system, I should ask but this has always proved futile by the assembly saying they are financially constrained". The core management team member hastened to add that; "I do not know if it is now that such funds will be made available to support the development of the system".

A critical look at the response explains that the District Assembly does not comply with the by-laws of the MLGRD and CWSA. The result confirms Adank et al. [12] and Kumasi et al.'s [13] statements that funding from district as- semblies are often unreliable and leads to extended periods of service downtime or substandard water service delivery. The findings also support Fonseca et al.'s [15] statement that even though the by-laws support back-up or external support, in practice, it is not done. This could be attributed to the fact that audit reports to the authorities at the assemblies suggest that the financial sustainability of the water system is in a better financial position to enable the system work on many of the issues when the need arises.

Furthermore, since water may be flowing continuously and everything seems to be working without any challenge of water shortages, patrons may have no reason to comply. Similarly, aside from financial constraints, to cater for communities that do not have a continuous water supply or even if available, a source that is free of water-borne diseases, most MMDAs, although they should have complied with the by-laws, they do not normally comply.

In Ghana, the by-laws developed towards the management of water requires all WSMT to operate three separate accounts, viz. the operational account, the sanitation account and the capital account. A key informant interview to solicit information about which accounts (as stipulated in the MLGRD and the CWSA tariff guidelines) the water system operates revealed that all the three accounts were operated by the system. The study revealed that the various deductions into the respective accounts and their stipulated percentages were transferred into the sanitation and capital accounts, respectively, as confirmed by the audit report. The review found that about $10 \%$ of the net revenue was transferred into the sanitation account. This implies that the mandated transfers were adhered to by the management team after paying for all regular operations and maintenance costs as stipulated by the CWSA tariff guidelines. The guidelines state that not less than $10 \%$ of net revenue (after paying for all regular operations and maintenance costs) should be transferred into the sanitation account. From the document review it was observed that following further provisions in the guidelines, the total transfer or deposits into the capital account was about 20\% of the net revenue (after paying for all regular operations and maintenance costs).

\section{Conclusions and Policy Recommendations}

The study contributes to the understanding of revenue used for operations and maintenance in small town water supply systems in Ghana while contributing to the empirical literature concerning Ghanaian community-managed water supply services. The study revealed that $60.98 \%$ of the beneficiaries perceived that the money they paid was sufficient to replace the infrastructure. Averagely, to a very good extent and with a perception index of 3.3, the beneficiaries had a positive perception on revenue being able to cover operations and maintenance, expansion and replacement of the infrastructure. The review from the existing document showed that between $15.8 \%$ and $16.2 \%$ of the system's total revenue was spent on operations and maintenance, 
indicating that the system's revenue was sufficient to pay for operations and maintenance as far as the system's management was concerned. The review also showed that although private connections generated $36 \%$ of the total revenue, the management of the system was not able to recover all monies from its private connection customers. However, a distinct perspective that considers the use of environmentally friendly innovations to promote environmental sustainability for water supply services without an effect on the environment or beneficiaries or services is critical to achieving financial sustainability.

Building on the aforementioned finding, the following recommendations are made. Firstly, it is important to stress the need to ensure that appropriate strategies are adapted to retrieve the unpaid bills from the customers and not on an ad-hoc basis where the monies are collected only when it is needed. Secondly, it is recommended that the Water Management Team should invest in educating the public thoroughly on the need for them to always pay their bills. Thirdly, the financial management aspect of the system needs to be improved through sensitization and awareness creation. Furthermore, management should consider consistent debt recovery strategies, similar to the public standpipe pay-asyou-fetch, for private users. Finally, pre-paid metering for private/domestic users would be the appropriate alternative for management to stay committed and collect user fees regularly while minimizing and, if possible, avoiding debts in order to support in financing major operations and maintenance works.

\section{Acknowledgments}

The authors sincerely acknowledge the valuable comments of two anonymous reviewers and the editor. Secondly, we acknowledge Next Generation Researchers (NGR) of Kwame Nkrumah University of Science and Technology, Kumasi, Ghana, for providing financial support for the data collection aspect of the research. NGR are implementers of Education for Sustainable Development in Africa (ESDA) project funded by the African Development Bank Japan Trust Fund ("JTF"). We are also grateful to the Water and Sanitation Management Team (WSMT) of Jacobu in the Ashanti Region of Ghana for providing secondary data for the study. To the beneficiaries of the Jacobu water supply system who responded to our questionnaire, we are most grateful. Finally, we acknowledge the proofreading services provided by Hughes Bib that helped to improve the language of the paper.

\section{References and Notes}

[1] Nti EK, Wongnaa CA, Edusah NSE, Bakang JEA. Assessment of the Sustainability of Community-managed Water Supply Services in Ghana. Environment, Development and Sustainability. 2019;pp. 1-24. doi:10.1007/s10668-019-00506-1.

[2] "Implementation Completion Report: Third Rural Water Supply and Sanitation Project.". Washington, DC, USA: World Bank; 1999.

[3] Lockwood H, Bakalian A, Wakeman W. Assessing Sustainability in Rural Water Supply: The Role of Follow-up Support to Communities. Literature Review and Desk Review of Rural Water Supply and Sanitation Project Documents. Bank-Netherlands Water Partnership (BNWP); 2003. Available from: https://www.aguaconsult.co.uk/wpcontent/uploads/WorldBank_PostConstructionStudy_2003-1.pdf.

[4] Bakalian A, Wakeman W. Post-Construction Support and Sustainability in Community-Managed Rural Water Supply: Case Studies in Peru, Bolivia, and Ghana. In: Water Sector Board discussion paper series no. 14. World Bank; 2009. Available from: https://openknowledge.worldbank.org/handle/10986/17246.

[5] Allan T. The Middle East Water Question: Hydropolitics and the Global Economy. Bloomsbury Publishing; 2012.

[6] Al-Shueili AAM. Financial Sustainability of the Water Sector in the Sultanate of Oman [PhD Thesis]. Loughborough University; 2014. Available from: https://repository.lboro.ac.uk/ndownloader/files/17077202/ 1.

[7] Gupta S, Zeithaml V. Customer Metrics and their Impact on Financial Performance. Marketing Science. 2006;25(6):718-739. doi:10.1287/mksc.1060.0221.

[8] Rodríguez Bolívar MP, Navarro Galera A, Alcaide Munoz L, López Subires MD. Analyzing Forces to the Financial Contribution of Local Governments to Sustainable Development. Sustainability. 2016;8(9):925. doi:10.3390/su8090925.

[9] Akinyi AM, Odundo PA. Revenue Generation Aspects That Influence Financial Sustainability of Public Water Utilities in Kenya: The Case of Homa Bay Water and Sewerage Company Limited. Asian Business Research. 2018;3(2):1. doi:10.20849/abr.v3i2.370.

[10] McPhail A, Locussol AR, Perry C. Achieving Financial Sustainability

and Recovering Costs in Bank Financed Water Supply and Sanitation and Irrigation Projects. In: Water papers. Washington, DC, USA: World Bank; 2012. Available from: http://hdl.handle.net/10986/17226.

[11] Burr P, Kumasi TC, Franceys R. Assessing the Scope for Rural Water Infrastructure Asset Management in Ghana. The Hague, The Netherlands: International Water and Sanitation Centre (IRC); 2013. doi:10.13140/RG.2.2.24057.52326.

[12] Adank M, Kumasi T, Abbey E, Dickinson N, Dzansi P, Atengdem J, et al. The Status of Rural Water Supply Services in Ghana. A Synthesis of Findings from 3 Districts. Triple-S Working Paper, IRC Ghana, Accra, Ghana. The Hague, The Netherlands: International Water and Sanitation Centre (IRC); 2013. doi:10.13140/RG.2.2.22799.23200.

[13] Kumasi TC, Kubabom B, Abbey E, Nunoo W, Konadu O, Ayi-Bonte V. Innovative Financing for Capital Maintenance Expenditure in Small Towns Water Systems in Three Districts in Ghana. IRC-CWSA Publication; 2017. Available from: https://www.ircwash.org/sites/default/ files/innovative_financing_report_27.11.17.pdf.

[14] Barraqué B. Full Cost Recovery of Water Services and the 3 T's of OECD. Utilities Policy. 2020;62:100981. doi:10.1016/j.jup.2019.100981.

[15] Fonseca C, Smits S, Nyarko K, Naafs A, Franceys R. Financing Capital Maintenance of Rural Water Supply Systems: Current Practices and Future Options. The Hague, The Netherlands: IRC International Water and Sanitation Centre; 2013. Available from: https://www. ircwash.org/sites/default/files/201303_9_wp_capmanex_web.pdf.

[16] Progress on Sanitation and Drinking Water-2015 Update and MDG Assessment. Geneva, Switzerland: World Health Organization (WHO); 2015. Available from: https://www.unicef.org/reports/ progress-sanitation-and-drinking-water.

[17] Nyarko KB. Drinking Water Sector in Ghana. Drivers for Performance. Routledge, Taylor \& Francis Group; 2007. Available from: https: //www.routledge.com/Drinking-Water-Sector-in-Ghana-Drivers-forPerformance-PhD-UNESCO-IHE/Nyarko/p/book/9780415453660.

[18] Kumasi TC. Financing Sustainable Water Service Delivery of Small Town Water Systems in Ghana: The Gaps and Needs. Journal of Sustainable Development of Energy, Water and Environment Systems. 2018;6(3):427-445. doi:10.13044/j.sdewes.d6.0195.

[19] Herrick CN, Pratt JL. Communication and the Narrative Basis of 
Sustainability: Observations from the Municipal Water Sector. Sustainability. 2013;5(10):4428-4443. doi:10.3390/su5104428.

[20] Kalbermatten J, Revels C, Kariuki M, Pilgrim N, Roche B. Principles of Town Water Supply and Sanitation-Part 1: Water Supply. Washington, DC, USA: Bank Netherlands Water Partnership (BNWP);. Available from: https: //documents1.worldbank.org/curated/en/339701468140984353/pdf/ 442230REPLACEM1ument10WN131TownsWSS.pdf.

[21] Ryan P, Adank M. Global Best Practice in the Management of Small Town Water Supplies. Accra, Ghana: IRC International Water and Sanitation Centre; 2010. Available from: https://www.washghana.net/ sites/default/files/a4d9a0813a260dc3d51f6808cb4c8a4e.pdf.

[22] Wichelns D. Enhancing the Performance of Water Prices and Tariff Structures in Achieving Socially Desirable Outcomes. International Journal of Water Resources Development. 2013;29(3):310326. doi:10.1080/07900627.2012.721675.

[23] Rehan R, Knight MA, Unger AJA, Haas CT. Development of a System Dynamics Model for Financially Sustainable Management of Municipal Watermain Networks. Water Research. 2013;47(20):7184-7205. doi:10.1016/j.watres.2013.09.061.

[24] Whaley L, Cleaver F. Can 'Functionality' Save the Community Management Model of Rural Water Supply? Water Resources and Rural Development. 2017;9:56-66. doi:10.1016/.jwr.2017.04.001.

[25] Hutchings P. Supporting Community Management: A Synthesis of Successful Rural Water Services Programmes in India [PhD Thesis]. School of Water, Energy and Environment, Cranfield University. Cranfield, UK; 2016. Available from: http://dspace.lib.cranfield.ac.uk/ handle/1826/11314

[26] Hutchings P, Chan MY, Cuadrado L, Ezbakhe F, Mesa B, Tamekawa C, et al. A Systematic Review of Success Factors in the Community Management of Rural Water Supplies Over the Past 30 Years. Water Policy. 2015;17(5):963-983. doi:10.2166/wp.2015.128.

[27] Moriarty P, Smits S, Butterworth J, Franceys R. Trends in Rural Water Supply: Towards a Service Delivery Approach. Water Alternatives. 2013;6(3):329. Available from: https://www.wateralternatives.org/index.php/volume6/v6issue3/220-a6-3-1/file.

[28] Braimah I, Filmua N. Community Ownership and Management of Water and Sanitation Facilities: Issues and Prospects in the Nadowli District of the Upper West Region of Ghana. Journal of Sustainable Development in Africa. 2011;13(3):74-87. Available from: https://www.semanticscholar.org/paper/COMMUNITYOWNERSHIP-AND-MANAGEMENT-OF-WATER-AND-ANDBraimah-Fielmua/ea6c578e9a8297d776f2a9ac307512ccb41026f7.

[29] National Community Water and Sanitation Strategy (NCWSS). Decentralised Water Management under the National Community Water and Sanitation Programme. Accra, Ghana: Community Water Sanitation Agency (CWSA); 2007. Available from: http://extwprlegs1.fao. org/docs/pdf/gha182900.pdf

[30] Amerasinghe NM. A Study of the Factors Affecting the Sustainability of Community Managed Rural Water Supply Schemes in Sri Lanka [MSc Thesis]. Cambridge, MA, USA; 2009. Available from: https://dspace.mit.edu/bitstream/handle/1721.1/49740/ 449967319-MIT.pdf?sequence=2\&isAllowed=y.

[31] Water Supply \& Sanitation in Africa: Findings, Lessons and Good Practices to Improve Delivery. Abidjan, IC: Independent Development Evaluation and African Development Bank Group; 2015. Available from: https://www.pseau.org/outils/ouvrages/bad_water_supply sanitation_in_africa_findings_lessons_and_good_practices_to_ improve_delivery_2015.pdf.

[32] Lockwood H, Smits S. Supporting Rural Water Supply. Practical Action Publishing; 2011. Available from: https://doi.org/10.3362\% 2F9781780440699. doi:10.3362/9781780440699.

[33] Baumann E. Do Operation and Maintenance Pay? Waterlines. 2006;25(1):10-12. Available from: https://www.ircwash.org/sites/ default/files/Baumann-2006-Do.pdf.

[34] Harvey PA, Reed RA. Community-managed Water Supplies in Africa: Sustainable or Dispensable? Community Development Journal. 2006;42(3):365-378. doi:10.1093/cdj/bsl001.
[35] Schouten T, Moriarty P. Community Water, Community Management: From System to Service. Draft International Water and Sanitation Centre-IRC and ITDG; 2003.

[36] Community Water and Sanitation Regulation. (Operation and Maintenance Guidelines). Accra, Ghana: Community Water and Sanitation Agency (CWSA) and Goverment of Ghana; 2011.

[37] Franceys R, Pezon C. Services are Forever: The Importance of Capital Maintenance (CapManEx). The Hague, the Netherlands; 2010. Available from: www.washcost.info/page/866.

[38] Operations and Maintenance Guidelines for Small Towns. Accra, Ghana: Community Water and Sanitation Agency (CWSA) and Goverment of Ghana; 2010. Available from: https://gs.gov.gh/wp-content/ plugins/download-attachments/includes/download.php?id=588.

[39] 2010 National Housing and Population Census; Population by District and Sex. Accra, Ghana: Ghana Statistical Service GSS; 2014. Available from: https://www2.statsghana.gov.gh/docfiles/2010_District Report/Ashanti/AMANSIE\%20CENTRAL.pdf.

[40] Operations and Maintenance Manual for Jacobu Water Supply System Management Team. Jacobu, Ghana: JSTWSS, Jacobu Water Supply System; 2009.

[41] Yamane T. Statistics: An Introductory Analysis. vol. 886. Harper \& Row New York; 1967.

[42] Bowen GA. Document Analysis as a Qualitative Research Method. Qualitative Research Journal. 2009;9(2):27. doi:10.3316/QRJ0902027.

[43] Corbin J, Strauss A. Basics of Qualitative Research: Techniques and Procedures for Developing Grounded Theory. Sage Publications; 2014.

[44] Angrosino MV, Mays de Pérez KA. Rethinking Observation. From Method to Context. Teoksessa NK Denzin \& YS Lincoln (toim.) Handbook of Qualitative Research. Thousand Oaks, CA, USA: Sage; 2000.

[45] Baruch Y. Response Rate in Academic Studies-A Comparative Analysis. Human Relations. 1999;52(4):421-438. doi:10.1177/001872679905200401.

[46] O'Leary Z. Primary data: Surveys, interviews and observation. In: The Essential Guide to Doing your Research Project; 2014. pp. 201-216. Available from: http://www.ru.ac.bd/wp-content/uploads/ sites/25/2019/03/402_06_00_0\%E2\%80\%99Leary-The-EssentialGuide-to-Doing-Your-Research-Project-2017.pdf.

[47] Espinosa G. The Influence of Religion on Latino Education, Marriage, and Social Views in the United States. Marriage \& Family Review. 2008;43(3-4):205-225. doi:10.1080/01494920802072439.

[48] Orbuch TL, Veroff J, Hassan H, Horrocks J. Who Will Divorce: A 14-year Longitudinal Study of Black Couples and White Couples. Journal of Social and Personal Relationships. 2002;19(2):179-202. doi:10.1177/0265407502192002.

[49] Stanley SM, Amato PR, Johnson CA, Markman HJ. Premarital Education, Marital Quality, and Marital Stability: Findings from a Large, Random Household Survey. Journal of family psychology. 2006;20(1):117. doi:10.1037/0893-3200.20.1.117.

[50] Kaur B, Hassan Z. Impact of Age, Gender, Income, Education and Financial Literacy towards Retirement Planning among Generation ' $Y$ ' in Malaysia. International Journal of Education, Learning and Training. 2018;3(1). doi:10.24924/ijelt/2018.11/v3.iss1/30.53.

[51] Bolívar MPR, Galera AN, Muñoz LA. New Development: The Role of Accounting in Assessing Local Government Sustainability. Public Money \& Management. 2014;34(3):233-236. doi:10.1080/09540962.2014.908035.

[52] Lopez-Subires MD, Alcaide-Munoz L, Navarro-Galera A, RodriguezBolivar MP. The Influence of Socio-Demographic Factors on Financial Sustainability of Public Services: A Comparative Analysis in Regional Governments and Local Governments. Sustainability. 2019;11(21):6008. doi:10.3390/su11216008.

[53] District Assemblies Model Bye-Law-Establishment and Operations of Water and Sanitation Development Boards. Accra, Ghana: Ministry of Local Government and Rural Development (MLGRD); 2008. 